\title{
Ecological planning strategies for urban parks based on biodiversity conservation and promotion: a case study of Qingxiushan Forest Park in Nanning City
}

\author{
Shuang Ming ${ }^{1, *}$, Qin Du ${ }^{1}$ \\ ${ }^{1}$ School of Tourism and Landscape Architecture, Guilin University of Technology, 541006 Guilin, Guangxi, China
}

\begin{abstract}
Urban biodiversity plays an important role in maintaining urban ecosystem, beautifying urban environment, improving economic benefits and human well-being, and urban park, as an important habitat of urban biology, is an important part of urban biodiversity. Taking Qingxiu Mountain Park in Nanning City as an example, this paper analyzes the main problems and challenges of biodiversity conservation and promotion, and puts forward a scientific reference basis for the promotion and protection of biodiversity in Qingxiu Mountain Park in Nanning City.
\end{abstract}

\section{Introduction}

\subsection{The concept of urban biodiversity and its importance}

Urban biodiversity refers to the collection of wild animals, plants, microorganisms and other biological species in the physical environment of a city. The promotion of urban biodiversity plays an important role in maintaining the urban ecosystem, beautifying the urban ecological environment, improving economic benefits and human well-being ${ }^{[1]}$. In 2002, world leaders pledged to significantly reduce the rate of biodiversity loss by 2010 through the Convention on Biological Diversity, Despite extensive response measures, the rate of biodiversity loss does not seem to slow down ${ }^{[2]}$. Among them, many papers pointed out that biodiversity and species composition present obvious urban-rural gradient change, This suggests that urbanization is one of the most important drivers of species decline, homogenization and extinction compared to other human activities.

\subsection{Research on Biodiversity of Urban Parks}

Urban park is fragmented habitat patch preserved in the rapid progress of urbanization, with good landscape resources, diverse landforms, rich wildlife species and other characteristics. Park is often an important habitat of urban wildlife, is an important part of the urban ecosystem, so the protection and promotion of park biodiversity is an important link to improve the quality of urban environment,to create a good living environment. Chen Bo et al. pointed out that urban parks and suburban parks often have highly diverse habitats,By comparing the methods of park biodiversity assessment in China and
Belgium, they proposed a set of index framework suitable for park biodiversity assessment in China ${ }^{[3]}$. Wang Min et al. proposed a framework for biodiversity design of urban parks based on the classification system of habitat units by analyzing the cases of park biodiversity improvement at home and abroad ${ }^{[4]}$. Hao Sheng et al. evaluated the biodiversity of Minghu National Wetland Park in Liupanshui by taking Minghu National Wetland Park as an example, confirmed that the level of biodiversity was improved after the park was designed and completed, and put forward optimization strategies and suggestions for the promotion and protection of biodiversity in the $\operatorname{park}^{[5]}$.Zhao Caijun et al. took Perth, Australia as an example, introduced the design, construction and management of King's Park and Bird's Park, and summarized the strategies and methods to improve the biodiversity of urban parks ${ }^{[6]}$. In addition, the biodiversity design of more domestic urban parks is mainly to achieve the purpose of habitat diversity and biological species diversity by utilizing plant characteristics, matching plant community configuration and building biological habitats within the scope of urban public green space or wetland.

\section{Regional Overview}

\subsection{Geographic location and Qingxiu Mountain Forest Park}

Nanning City is located at $22^{\circ} 13^{\prime} \sim 23^{\circ} 32^{\prime} \mathrm{N}, 107^{\circ} 45^{\prime} \sim$ $108^{\circ} 51$ 'E. Its topography is typical of mountains, hills and basins, with an average elevation of 76.5 meters. Nanning has a mild climate, abundant rainfall, and an average annual temperature of $21.7^{\circ} \mathrm{C}$, belonging to the subtropical monsoon climate, which provides good living conditions for organisms, and has the reputation of China's Green City. As of February 2021, the city has

\footnotetext{
* Corresponding author: 1017045714@qq.com
} 
jurisdiction over 7 districts, 4 counties and 1 city, with a total area of 22,112 square kilometers, including 372 square kilometers of built-up areas. The city has a permanent population of 7.3448 million and an urban population of 4.6788 million, accounting for an urbanization rate of 63.7 percent.

Qingxiu Mountain Park is located on the banks of Yongjiang River in Nanning City, Guangxi Zhuang Autonomous Region. Scenic spots include three mountain ranges, namely Phoenix Ridge, Fengyi Ridge and Qingxiu Mountain, with an altitude of 82-289 meters. The planned protected area of Qingxiu Mountain Scenic Spot is 13.54 square kilometers, the core protected area is about 5.86 square kilometers, and the forest plant park is about 7.68 square kilometers. The unique landscape resources and abundant animal and plant resources make Qingxiu Mountain known as the green lung of Nanning City, which plays an important role in the urban green space system planning of Nanning City.

\subsection{Status of biological resources}

The favorable climatic conditions and advantageous geographical location provide a good living environment for the flora and fauna resources in Qingxiu Mountain. According to the investigation of researchers, there are 174 families, 752 genera and 1431 species of vascular plants in Qingxiu Mountain Scenic Area, including 21 families of ferns. There are 36 genera and 48 species, 8 families, 14 genera and 42 species of gymnosperms, 145 families, 702 genera and 1,341 species of angiosperms. There are 997 species of cultivated plants, belonging to 156 families and 535 genera $^{[7]}$. Among them, along the Qingxiu Mountain Ancient Road with less human intervention is a very rare area of native plant distribution in the city center, where you can see the naturally distributed plant communities of Nanning. Qingxiu mountain wildlife resources are relatively abundant, in terms of birds, currently in mountain has four kinds of wild animals under state protection (category ii) was observed Crested Goshawk (Accipiter trivirgatus), Asian Barred Owlet (Glaucidium cuculoides), Collared Scops Owl (Otus bakkamoena) Greater coucal (Centropus sinensi)in the breeding. In addition, Mount Qingxiu is also an important breeding, habitat and foraging ground for many other birds,Examples such as Hill Blueflycatcher(Cyornis banyumas), Ashy Minivet (Pericrocotus divaricatus), Lesser Shortwing(Brachypteryx leucophris), White-bellied Yuhina(Erpornis zantholeuca), etc. Japanese Robin (Erithacus akahige) have been observed wintering here for years. In terms of amphibians, reptiles, insects, Trirope beauty snake(Coelognathus radiatus), Dorsal-striped Opposite-fingered Treefrog(Chiromantis doriae), and Original-tail gecko(Hemidactylus bowringii) are common wild animals in Qingxiu Mountain. These data all show that Qingxiu Mountain Park has abundant wild animal and plant resources, and protecting and improving the biodiversity of Qingxiu Mountain is an indispensable part of the planning and design.

Table1. List of Common Birds in Qingxiu Mountain.

\begin{tabular}{|c|c|c|c|c|}
\hline Order & Family & pecies & scientific name & Protection level \\
\hline Accipitriformes & Accipitridae & Crested Goshawk & Accipiter trivirgatus & $\begin{array}{c}\text { National two levels } \\
\text { of protections } \\
\text { animals }\end{array}$ \\
\hline Strigiformes & Strigidae & Asian Barred Owlet & Glaucidium cuculoides & $\begin{array}{l}\text { National two levels } \\
\text { of protections } \\
\text { animals }\end{array}$ \\
\hline Strigiformes & Strigidae & Collared Scops Owl & Otus lettia & $\begin{array}{c}\text { National two levels } \\
\text { of protections } \\
\text { animals }\end{array}$ \\
\hline Cuculiformes & Cuculidae & Greater coucal & Centropus sinensis & $\begin{array}{c}\text { National two levels } \\
\text { of protections } \\
\text { animals }\end{array}$ \\
\hline Passeriformes & Old World babbler & Hill Blue-flycatcher & Cyornis banyumas & \\
\hline Passeriformes & Campephagidae & Ashy Minivet & $\begin{array}{c}\text { Pericrocotus } \\
\text { divaricatus }\end{array}$ & $\begin{array}{l}\text { Key protected } \\
\text { animals }\end{array}$ \\
\hline Passeriformes & Vireonidae & $\begin{array}{c}\text { White-bellied } \\
\text { Yuhina }\end{array}$ & Erpornis zantholeuca & \\
\hline Passeriformes & Turdidae & Japanese Robin & Erithacus akahige & \\
\hline Passeriformes & Muscicapidae & Lesser Shortwing & $\begin{array}{c}\text { Brachypteryx } \\
\text { leucophrys }\end{array}$ & \\
\hline
\end{tabular}

\section{Challenges and problems}

\section{1 invasive alien species}

Biological invasion has become one of the most important factors that threaten biodiversity in the world,Due to the lack of natural enemies and strong reproductive capacity,invasive alien species often bring threats to native species and destroy the balance of ecosystem and species diversity,Its threat to biological species has attracted enough attention in the global scope. In recent years, the invasion of alien species has become increasingly harmful to the biodiversity of China, which has threatened the ecological security of China. 
According to Chen Ting's statistics, there are 787 local plants (plants distributed in Guangxi) in Qingxiu Mountain, 72 plants introduced from other provinces of China, and 257 plants introduced and cultivated from abroad[8]. The results showed that the exotic plants in Qingxiu Mountain accounted for a large part of the total plants. Among them, there are a large proportion of exotic plants in the botanical gardens such as cycad gardens and palm gardens, and these exotic plants are likely to bring other exotic wild animals and plants with them during the introduction process, which will bring serious threats to the native species.

\subsection{Habitat fragmentation}

Due to the acceleration of urbanization in Nanning, the change of land use around Qingxiu Mountain Park and the influence of various garden building activities in Qingxiu Mountain Park, the wild animals and plants in the park are facing the problem of habitat loss and fragmentation. Hard squares and roads, as well as the application of artificial materials, have resulted in the continuous shrinking of biological habitat, loss of living and reproduction space, and a continuous decline in the quantity and quality of biological diversity.

\subsection{Artificial interference}

Qingxiu Mountain Park, a 5A scenic spot, receives more than 2.6 million visitors annually, including 300,000 during the Spring Flower Festival. All these data show that the tourists in Qingxiu District are so crowded that artificial interference is more serious, which is not conducive to the reproduction and communication of some sensitive wild animals. In addition, forest fires and environmental pollution caused by human factors are also one of the main factors causing the loss of biodiversity.

\section{4 case study}

The High Line in New York City was built in 1930 as an elevated route to transport meat supplies. It was designed to improve traffic congestion and safety in southwest Manhattan so that meat and milk could be transported into the city. Therefore, it was also called the transportation lifeline. After 1980 the lifeline fell into disuse and threatened to be demolished by the development of the transportation industry. The Hudson River and native birds brought seeds and landscape to the High Line. In order to preserve the natural High Line landscape, local travel journalists and entrepreneurs created a nonprofit organization to protect the High Line -- Friends of the High Line. Through the joint efforts of government, citizens, designers, entrepreneurs and philanthropists, the High Line park was saved and opened to the public in 2009. The High Line is 2.33 kilometers long, 9 meters above the ground and 9 meters wide on average. It runs through 22 blocks with 11 entrances and exits. Elevated park a total of more than 500 kinds of plants, shrubs, perennial trees and flowers and the plants attract bees, butterflies, birds and other insects, local Banks with a bee agencies, bees in the park, by raising bees, park and nearby need pollination on the growth of the plant are better, they produce honey also through the charity sale activity, used to run in the park. It is estimated that between 2007 and 2027, the High Line will generate \$1.4 billion in tax revenue for New York City and indirectly generate $\$ 5$ billion in development in the surrounding area. In addition, the construction of the elevated park achieved great social benefits, friends of the contour with the development of volunteer the nature of the many activities, such as biodiversity, share park plant experience, art exhibitions, family entertainment, education and so on a series of public activities, good interactive activities for a long time to also make many new yorkers to volunteer to give back to the park. More broadly, the Friends of the High Line formed the High Line Parks Network to share the success of the High Line with other cities. So far, 19 US cities have joined the network and set up their own public space projects, such as the renovation of space under the bridge in Miami.

\section{Ecological planning strategies}

\section{1 attach importance to the water space in the park}

Drainage space such as lakes and rivers have high biological richness, is one of the important habitats, aquatic animals and plants and amphibians. In the ecological planning and design of parks, park managers should pay attention to the blue space such as lakes, ponds and wetlands, and actively utilize the water system of parks to create habitat space suitable for the survival, reproduction and communication of aquatic animals and amphibians. At present, the water environment in Qingxiu Mountain is dominated by lakes, with large spatial distribution and poor connectivity, which is not conducive to water exchange, resulting in the decline of water ecosystem quality and reduction of aquatic organisms. In the ecological planning of Qingxiu Mountain, all waterscape resources in the park should be integrated, communicate and connect the existing water system, enhance the connectivity of the water system in the park, form the blue network of Qingxiu Mountain Park, and enrich the habitat space of aquatic animals and plants. Secondly, the combination of blue and green is conducive to the integration of natural resources in the park, ensuring the environment and quality of the habitat, and thus improving the regional species richness. The landscape area of qingxiu district should make full use of the biological advantages of the biggest river in Nanning, yongjiang river and its tributaries, make landscape according to the water, and distribute green transition zone on the skeleton of the blue space in the park, so as to form the biological living space in the park with blue and green fusion.

\section{2 level protection for focus species}

Qingxiu Mountain is an important habitat for Guangxi District Key Protected Animals, National I Class 
Protected Animals, Class II Key Protected Animals and Plants, and Endangered Animals and Plants,It is very necessary to focus on the protection of these precious animals and plants. In the main action plan of ecological protection of Qingxiu Mountain, the status quo and spatial distribution of the rare plant and animal resources in the park should be sorted out and summarized, and the methods of listing and explaining the rare plants, drawing red lines and hierarchical protection should be adopted. For the rare wild animals in the park, the protection red line should be drawn to reduce human interference, and the shelter effect of plants should be used to create the wildlife habitat in the park, so as to ensure the safety of the endangered wildlife habitat. In terms of food sources, attention should be paid to the water and food sources of wild animals in the park, water features should be built near the habitats, and some tree species that wild animals like to eat should be selected for planting, so as to attract more wild animals to enter the habitats for foraging and communication.

\subsection{Choose native species to enrich plant communities in the park}

In order to build a thousand-year-old cycad garden, peach garden, palm garden and other special plant gardens in Qingxiu Mountain Park, many plants are introduced and cultivated from abroad. This practice not only poses an invisible threat to the native species in the garden, but also Introduced species do not adapt to the local climate and do not grow well, which wastes a lot of human and financial resources. Local species, such as Mangifera indica L, Artocarpus heterophyllus Lam,and Dracontomelon duperreanum Pierre should be adopted as far as possible in plant community construction, so as to enhance the seasonal landscape changes of plants and improve the stability of regional ecosystem.

\subsection{Applied edge effect}

Edge effect refers to the phenomenon that the number and species of organisms in the ecotone of the ecosystem are more than those in the adjacent ecosystem due to the influence of foraging, communication and reproduction of organisms. In the ecological planning of Qingxiu Mountain, the principle of edge effect should be actively used to transform the junction of the two ecosystems and improve the biodiversity of the edge of the ecosystem by means of growth, broadening and zigzagzing. By optimizing the edge of Qingxiu Mountain Yanyu Lake, Tianchi Lake and other lakes, we can widen the lakeshore zone and transform the curvature of the lake shoreline, so as to increase the heterogeneity of the lake edge and improve the level of biodiversity.

\subsection{Improving methods for monitoring diversity of species}

At present, biodiversity monitoring is mainly applied to large protected areas and national parks, while biodiversity investigation on urban public green space is less. Therefore, Qingxiu Mountain should improve the monitoring methods of biological species and adopt a variety of methods to protect and monitor the wildlife in the park. Carry out civic science education activities, use civic science to record classification and monitor wildlife data in the park, lay a solid foundation for various scientific researches in the park, and combine multiprofessional experts to understand the resources of wild animals and plants in Qingxiu Mountain,Conduct longterm, large-scale, and professional investigations.

\section{Conclusion}

Biological diversity of urban parks is an important part of urban biological diversity, facing the severe challenge of biodiversity protection and promotion of urban parks, this paper combined with the actual situation of Qingxiu Mountain Park, put forward attach importance to the water space in the park, level protection for focus species,Choose native species to enrich plant communities in the park,Applied edge effect Improving methods for monitoring diversity of species. There are five strategies to improve the local biodiversity. It is expected to provide useful reference for the ecological planning of urban parks.

\section{References}

1. FULLER.R.A,IRVINE.K.N,DEVINEWRIGHT.P.Ps ychological benefits of greenspace increase with biodiversity, BIOLOGY LETTERS, 3(4): 390-394. 2007.

2. BUTCHART S H M, WALPOLE M, COLLEN B, Global Biodiversity: Indicators of Recent Declines,SCIENCE,328(5982):1164-1168,2010.

3. B.Chen,Z.Y.Bao,Indicators for biodiversity assessment in urban and suburban parks, Biodiversity, 1:169-176,2003.

4. M.Wang, Yan.Wang. Biodiversity design for urban parks,Landscape architecture, 47-52,2014.

5. S.HAO, C.L.Wang, H.W.Lin. Biodiversity design and assessment of urban wetland parks: A case study of Minghu National Wetland Park in Liupanshui,Acta Ecologica Sinica, 395967-5977, 2019.

6. C.J.Zha,Planning and Design of Urban Garden and Green Space Oriented by Protecting Urban Biodiversity: A Case Study of Perth, Australia, 2011 Conference on Urban Development and Planning, 2011.

7. J.D.Li, J.Pang, T.P.He, Flora of Qingxiu Mountain Scenic Area in Nanning City. Anhui Agricultural Sciences, 38: 10422-10425,2010.

8. T.Chen, Study on plant diversity in qingxiu mountain scenic spot of nanning city Urban Ecology,Guangxi University, 2005. 